\title{
Respiratory equations - behind the numbers
}

\section{T Leonard}

Department of Anaesthesia, School of Clinical Medicine, Faculty of Health Sciences, Chris Hani Baragwanath Academic Hospital, University of the Witwatersrand, South Africa

Corresponding author, email: tristan.leonard@wits.ac.za

\section{Summary}

Candidates for the FCA 1 exam will come across dozens of equations that eventually all merge into something complicated and daunting. The purpose of this review is to highlight some of the respiratory equations that are important and that candidates find confusing and explain the mathematical and physiological principles behind them.

Keywords: equations, respiratory physiology, ventilation, perfusion, dead space

\section{Introduction}

There are many equations that candidates will come across in their study of respiratory physiology. These equations describe principles of ventilation, perfusion and diffusion within the respiratory system. This review attempts to explain the origins and make sense of the numbers in some of these equations.

\section{Equations to be covered:}

- Dead space equations

- The alveolar gas equation

- Diffusion equations

- Ventilation-perfusion equations

\section{Dead space equations}

Physiological dead space represents the portion of ventilation that does not eliminate carbon dioxide $\left(\mathrm{CO}_{2}\right){ }^{1}$ This consists of the anatomical dead space (the fraction of ventilation delivered to the conducting airways - roughly $150 \mathrm{ml})^{1,2}$ and the alveolar dead space (the fraction of ventilation delivered to alveoli with no pulmonary artery perfusion). ${ }^{2}$ In 1891, Christian Bohr introduced his equation to represent the volume of gas that constitutes the dead space.

The original version of this equation is: ${ }^{2}$

$$
\begin{array}{cl}
\mathbf{V}_{\mathbf{D}} / \mathbf{V}_{\mathrm{T}}=\left(\mathbf{F}_{\mathbf{A}} \mathbf{C O}_{\mathbf{2}}-\mathbf{F}_{\mathbf{E}} \mathbf{C O}\right) / \mathbf{F}_{\mathbf{A}} \mathbf{C O} \mathbf{O}_{2} \\
\mathrm{~V}_{\mathrm{D}} & \text { respiratory dead space volume } \\
\mathrm{V}_{\mathrm{T}} & \text { tidal volume } \\
\mathrm{F}_{\mathrm{A}} \mathrm{CO}_{2} & \text { mean estimate of alveolar } \mathrm{CO}_{2} \text { concentration } \\
\mathrm{F}_{\mathrm{E}} \mathrm{CO}_{2} & \begin{array}{l}
\mathrm{CO}_{2} \text { concentration in the total mixed exhaled } \\
\text { breath }
\end{array}
\end{array}
$$

This equation has undergone some changes due to difficulties in measuring $\mathrm{F}_{\mathrm{A}} \mathrm{CO}_{2}$ and $\mathrm{F}_{\mathrm{E}} \mathrm{CO}_{2}$. Using Dalton's law (the concentration of a gas is proportional to its partial pressure) ${ }^{3}$ we can substitute $F_{A}$ and $F_{E}$ for partial pressures. ${ }^{4}$

$$
\begin{aligned}
& \mathrm{V}_{\mathrm{D}} / \mathrm{V}_{\mathrm{T}}=\left(\mathrm{P}_{\mathrm{A}} \mathrm{CO}_{2}-\mathrm{P}_{\mathrm{E}} \mathrm{CO}_{2}\right) / \mathrm{P}_{\mathrm{A}} \mathrm{CO}_{2} \\
& \mathrm{P}_{\mathrm{A}} \mathrm{CO}_{2} \text { partial pressure of } \mathrm{CO}_{2} \text { in alveolar gas } \\
& \mathrm{P}_{\mathrm{E}} \mathrm{CO}_{2} \text { partial pressure of } \mathrm{CO}_{2} \text { in the total mixed }
\end{aligned}
$$

A further modification was made by Henrik Enghoff due to difficulties measuring the $\mathrm{P}_{\mathrm{A}} \mathrm{CO}_{2}{ }^{2}$ This gives the physiological dead space equation: ${ }^{1}$

$$
\begin{array}{cl}
\mathbf{V}_{\mathrm{D}} / \mathrm{V}_{\mathrm{T}}=\left(\mathbf{P}_{\mathrm{a}} \mathbf{C O}_{2}-\mathbf{P}_{\mathrm{e}} \mathbf{C O}_{2}\right) / \mathbf{P}_{\mathrm{a}} \mathbf{C O}_{2} \\
\mathrm{~V}_{\mathrm{D}} & \text { physiological dead space volume } \\
\mathrm{V}_{\mathrm{T}} & \text { tidal volume } \\
\mathrm{P}_{\mathrm{a}} \mathrm{CO}_{2} & \begin{array}{l}
\text { partial pressure of carbon dioxide in arterial } \\
\text { blood }
\end{array} \\
\mathrm{P}_{\mathrm{e}} \mathrm{CO}_{2} & \text { partial pressure of carbon dioxide in expired } \\
& \text { gas }
\end{array}
$$

Important in this equation is understanding the derivation.

The derivation is based on the principal that only the gases involved in alveolar ventilation $\left(\mathrm{V}_{\mathrm{A}}\right)$ are involved in gas exchange and produce $\mathrm{CO}_{2}$. The total tidal volume $\left(\mathrm{V}_{\mathrm{T}}\right)$ is made up of $V_{A}+V_{D}$; we can substitute $V_{A}$ for $V_{T}-V_{D}{ }^{1,2,4}$

Now we must look at the fraction of expired $\left(\mathrm{F}_{\mathrm{E}}\right)$ and inspired $\left(\mathrm{F}_{\mathrm{i}}\right) \mathrm{CO}_{2}$. This can be done for nitrogen and oxygen, but $\mathrm{CO}_{2}$ is most commonly used.

In one exhalation the expired $\mathrm{CO}_{2}=\mathrm{F}_{\mathrm{E}} \cdot \mathrm{V}_{\mathrm{T}}$ and this must be made of alveolar gas and dead space gas. Therefore $\mathrm{V}_{\mathrm{T}} \cdot \mathrm{F}_{\mathrm{E}}=$ $\mathrm{V}_{\mathrm{A}} \cdot \mathrm{F}_{\mathrm{A}}+\mathrm{V}_{\mathrm{D}} \cdot \mathrm{F}_{\mathrm{i}}$ and it is assumed that the $\mathrm{F}_{1} \mathrm{CO}_{2}$ is 0 .

Therefore: ${ }^{1,2,4}$

$\mathrm{V}_{\mathrm{T}} \cdot \mathrm{F}_{\mathrm{E}}=\mathrm{V}_{\mathrm{A}} \cdot \mathrm{F}_{\mathrm{A}}$

Substitute $V_{A}$ for $V_{T}-V_{D}$

$\mathrm{V}_{\mathrm{T}} \cdot \mathrm{F}_{\mathrm{E}}=\left(\mathrm{V}_{\mathrm{T}}-\mathrm{V}_{\mathrm{D}}\right) \cdot \mathrm{F}_{\mathrm{A}}$

Multiply out the brackets 


$$
\begin{aligned}
& \begin{aligned}
\mathrm{V}_{\mathrm{T}} \cdot \mathrm{F}_{\mathrm{E}}= & \left(\mathrm{V}_{\mathrm{T}} \cdot \mathrm{F}_{\mathrm{A}}\right)-\left(\mathrm{V}_{\mathrm{D}} \cdot \mathrm{F}_{\mathrm{A}}\right) \\
& \text { Rearrange to get } \mathrm{V}_{\mathrm{D}} \text { on the left of the equation } \\
\mathrm{V}_{\mathrm{D}} \cdot \mathrm{F}_{\mathrm{A}}=\mathrm{V}_{\mathrm{T}}\left(\mathrm{F}_{\mathrm{A}}-\mathrm{F}_{\mathrm{E}}\right) & \\
& \text { Divide } \mathrm{V}_{\mathrm{T}} \text { and } \mathrm{F}_{\mathrm{A}} \\
\mathrm{V}_{\mathrm{D}} / \mathrm{V}_{\mathrm{T}}=\left(\mathrm{F}_{\mathrm{A}}-\mathrm{F}_{\mathrm{E}}\right) / \mathrm{F}_{\mathrm{A}} & \\
& \text { Substitute with partial pressure } \\
\mathrm{V}_{\mathrm{D}} / \mathrm{V}_{\mathrm{T}}= & \left(\mathrm{P}_{\mathrm{A}} \mathrm{CO}_{2}-\mathrm{P}_{\mathrm{E}} \mathrm{CO}_{2}\right) / \mathrm{P}_{\mathrm{A}} \mathrm{CO}_{2} \\
& \text { Now use the Enghoff modification } \\
\mathrm{V}_{\mathrm{D}} / \mathrm{V}_{\mathrm{T}}= & \left(\mathrm{P}_{\mathrm{a}} \mathrm{CO}_{2}-\mathrm{P}_{\mathrm{e}} \mathrm{CO}_{2}\right) / \mathrm{P}_{\mathrm{a}} \mathrm{CO}_{2}
\end{aligned}
\end{aligned}
$$

\section{The alveolar gas equation (AGE)}

The AGE describes the alveolar concentration (or partial pressure) of oxygen $\left(\mathrm{O}_{2}\right)$ in terms of the inspired oxygen concentration, the alveolar concentration of $\mathrm{CO}_{2}$ and the respiratory quotient $(\mathrm{R}) .^{5}$

$\mathrm{F}_{\mathrm{A}} \mathrm{O}_{2}=\mathrm{F}_{\mathrm{I}} \mathrm{O}_{2}-\left(\mathrm{F}_{\mathrm{A}} \mathrm{CO}_{2} / \mathrm{R}\right)$

Rewriting the equation applying Dalton's law again gives this equation:

$\mathbf{P}_{\mathrm{A}} \mathbf{O}_{2}=\mathbf{P}_{\mathrm{I}} \mathrm{O}_{2}-\left(\mathbf{P}_{\mathrm{A}} \mathrm{CO}_{2} / \mathrm{R}\right)$

$\mathrm{P}_{\mathrm{A}} \mathrm{O}_{2}$ alveolar partial pressure of $\mathrm{O}_{2}$

$\mathrm{P}_{\mathrm{I}} \mathrm{O}_{2}$ inspired partial pressure of $\mathrm{O}_{2}$

$\mathrm{P}_{\mathrm{A}} \mathrm{CO}_{2}$ alveolar partial pressure of $\mathrm{CO}_{2}$

$\mathrm{R}$ respiratory quotient

Derivation of the AGE:

To derive and understand the AGE (as well as its limitations) we need to look at each component of the equation.

\section{Carbon dioxide:}

At steady state all $\mathrm{CO}_{2}$ produced by the body $\left(\mathrm{VCO}_{2}\right)$ must be removed by the alveolar ventilation each minute and because $\mathrm{CO}_{2}$ is highly diffusible we can assume that $\mathrm{P}_{\mathrm{A}} \mathrm{CO}_{2}$ very closely approximates $\mathrm{P}_{\mathrm{a}} \mathrm{CO}_{2}{ }^{5}$

$\mathrm{VCO}_{2}=\mathrm{F}_{\mathrm{A}} \mathrm{CO}_{2} \times \mathrm{V}_{\mathrm{A}}$

Dalton's law of partial pressures needs to be applied again and states that in a mixture of gases the individual gas $\mathrm{CO}_{2}$ will be present in a concentration that is the same proportion as $\mathrm{P}_{\mathrm{A}} \mathrm{CO}_{2}$ is of the total pressure $\mathrm{P}_{1}{ }^{5}$

$\mathrm{VCO}_{2}=\left(\mathrm{P}_{\mathrm{A}} \mathrm{CO}_{2} / \mathrm{P}_{\mathrm{I}}\right) \times \mathrm{V}_{\mathrm{A}}$

The equation can be rearranged

$\mathbf{P}_{\mathrm{A}} \mathrm{CO}_{2}=\left(\mathrm{VCO}_{2} \times \mathbf{P}_{\mathrm{I}}\right) / \mathrm{V}_{\mathrm{A}}=\mathbf{P}_{\mathrm{a}} \mathrm{CO}_{2}$

\section{Oxygen:}

All oxygen entering the alveoli must equal the oxygen leaving the alveoli. Input into the alveoli is from the inspired air whereas the output of oxygen is a combination of oxygen consumption $\left(\mathrm{VO}_{2}\right)$ and expired oxygen. ${ }^{5}$

Input = output

$$
\begin{aligned}
& \text { Input }=\mathrm{V}_{\mathrm{A}} \times \mathrm{F}_{\mathrm{I}} \mathrm{O}_{2} \\
& \text { Output }=\mathrm{VO}_{2}+\left(\mathrm{V}_{\mathrm{A}} \times \mathrm{F}_{\mathrm{A}} \mathrm{O}_{2}\right) \\
& \mathrm{V}_{\mathrm{A}} \times \mathrm{F}_{\mathrm{I}} \mathrm{O}_{2}=\mathrm{VO}_{2}+\left(\mathrm{V}_{\mathrm{A}} \times \mathrm{F}_{\mathrm{A}} \mathrm{O}_{2}\right) \\
& \text { Solve for } \mathrm{VO}_{2} \\
& \mathrm{VO}_{2}=\mathrm{V}_{\mathrm{A}} \times\left(\mathrm{F}_{\mathrm{I}} \mathrm{O}_{2}-\mathrm{F}_{\mathrm{A}} \mathrm{O}_{2}\right)
\end{aligned}
$$

\section{Respiratory quotient:}

This is defined as "the volume of carbon dioxide released over the volume of oxygen absorbed during respiration. It is a dimensionless number used in the calculation for basal metabolic rate."

$\mathbf{R}=\mathrm{VCO}_{2} / \mathrm{VO}_{2}$

\section{The final derivation:}

$\mathrm{R}=\mathrm{VCO}_{2} / \mathrm{VO}_{2}=\left(\mathrm{F}_{\mathrm{A}} \mathrm{CO}_{2} \times \mathrm{V}_{\mathrm{A}}\right) /\left[\mathrm{V}_{\mathrm{A}} \times\left(\mathrm{F}_{\mathrm{I}} \mathrm{O}_{2}-\mathrm{F}_{\mathrm{A}} \mathrm{O}_{2}\right)\right]$

Cancel out $\mathrm{V}_{\mathrm{A}}$ in the numerator and denominator

$\mathrm{R}=\mathrm{F}_{\mathrm{A}} \mathrm{CO}_{2} /\left(\mathrm{F}_{\mathrm{I}} \mathrm{O}_{2}-\mathrm{F}_{\mathrm{A}} \mathrm{O}_{2}\right)$

Solve for $\mathrm{F}_{\mathrm{A}} \mathrm{O}_{2}$

$\left(\mathrm{F}_{\mathrm{I}} \mathrm{O}_{2}-\mathrm{F}_{\mathrm{A}} \mathrm{O}_{2}\right)=\mathrm{F}_{\mathrm{A}} \mathrm{CO}_{2} / \mathrm{R}$

$\mathrm{F}_{\mathrm{A}} \mathrm{O}_{2}=\mathrm{F}_{\mathrm{I}} \mathrm{O}_{2}-\mathrm{F}_{\mathrm{A}} \mathrm{CO}_{2} / \mathrm{R}$

Convert to partial pressures and assume $\mathrm{P}_{\mathrm{A}} \mathrm{CO}_{2}=\mathrm{P}_{\mathrm{a}} \mathrm{CO}_{2}$

$\mathrm{P}_{\mathrm{A}} \mathrm{O}_{2}=\mathrm{P}_{\mathrm{I}} \mathrm{O}_{2}-\left(\mathrm{P}_{\mathrm{a}} \mathrm{CO}_{2} / \mathrm{R}\right)$

This is AGE that is most often used. However, there is a problem with this equation in that it may be too simplistic when the value of $R$ does not equal 1.1,5 In the derivation of the AGE we substituted $\mathrm{R}$ for $\mathrm{VCO}_{2} / \mathrm{VO}_{2}$ and indeed when $\mathrm{R}=0.8$ as it most often does this would mean a $\mathrm{VCO}_{2}$ of $0.20 \mathrm{I} / \mathrm{min}$ and $\mathrm{VO}_{2}$ of $0.25 \mathrm{l} / \mathrm{min}$ which is a discrepancy of $50 \mathrm{ml}$ per minute.

Thus, the modified AGE is:1,5,7

$\mathbf{P}_{\mathrm{A}} \mathrm{O}_{2}=\mathrm{P}_{\mathrm{I}} \mathrm{O}_{2}-\left(\mathrm{P}_{\mathrm{a}} \mathrm{CO}_{2} / \mathrm{R}\right)+\left[\mathrm{F}_{\mathrm{I}} \mathrm{O}_{2} \times \mathrm{P}_{\mathrm{a}} \mathrm{CO}_{2} \times((\mathbf{1}-\mathrm{R}) / \mathrm{R})\right]$

The additional part of the equation has relatively minor effect in usual clinical practice.

\section{Diffusion equations}

In 1855 Adolf Fick described how a gas moves across a membrane. It is not an equation that can be solved with measurable numbers but rather shows the factors that affect the movement of a gas (oxygen) across the alveolar membrane. ${ }^{8}$

Flow of gas $\infty[\mathrm{A} \times \mathrm{D}(\mathrm{P} 1-\mathrm{P} 2)] / \mathrm{T}$

A

area of the membrane

$\mathrm{D}$

(P1 - P2)

diffusion constant of the gas

partial pressure (or concentration) gradient across the membrane

$\mathrm{T}$

thickness of the membrane

$\mathrm{D} \propto$ solubility of gas / $\sqrt{ }$ molecular weight of gas

This states that the rate of transfer of a gas is directly proportional to the area of a membrane, the diffusion constant 
for that gas and the concentration gradient across the membrane and it is inversely proportional to the thickness of the membrane. ${ }^{1,8}$

\section{Ventilation and perfusion relationship equations}

The concept of dead space has been discussed previously but there are two other equations that can be used to describe ventilation and perfusion relationships in the lung.

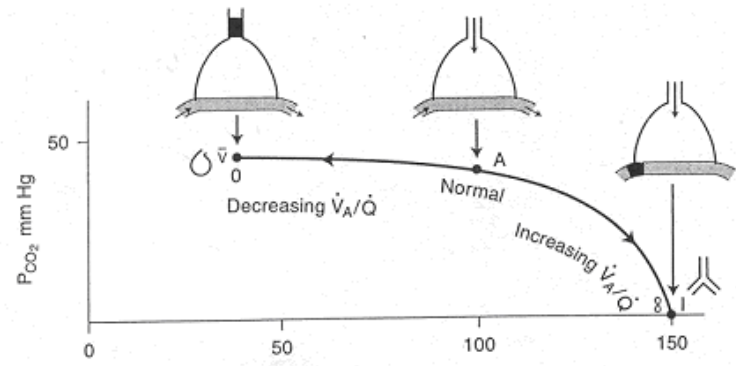

$\mathrm{P}_{2} \mathrm{~mm} \mathrm{Hg}$

Figure 1: $\mathrm{O}_{2}-\mathrm{CO}_{2}$ diagram showing a ventilation-perfusion $(\mathrm{V} / \mathrm{Q})$ ratio line ${ }^{1}$

The figure illustrates the relationship between alveolar $\mathrm{O}_{2}$ and $\mathrm{CO}_{2}$ partial pressure at varying $\mathrm{V} / \mathrm{Q}$ ratios. Numerically this can be described using the Bohr equation, V/Q ratio equation and the shunt equation.

\section{Ventilation-perfusion ratio equations:}

The basic V/Q ratio describes the ratio of ventilation to perfusion in the lung as a whole at a specific point in time. The equation below describes the overall V/Q relationship in the lung. ${ }^{9}$

$\mathrm{V}_{\mathrm{A}} / \mathrm{Q}=\left[8.63 \times \mathrm{R} \times\left(\mathrm{C}_{\mathrm{a}} \mathrm{O}_{2}-\mathrm{C}_{\mathrm{V}} \mathrm{O}_{2}\right)\right] / \mathrm{P}_{\mathrm{A}} \mathrm{CO}_{2}$

$\mathrm{V}_{\mathrm{A}} / \mathrm{Q} \quad$ ventilation-perfusion ratio

8.63 conversion constant

$\mathrm{R} \quad$ respiratory exchange ratio

$\left.\left(\mathrm{C}_{\mathrm{a}} \mathrm{O}_{2}-\mathrm{C}_{\mathrm{V}} \mathrm{O}_{2}\right)\right]$ difference in $\mathrm{O}_{2}$ content in arterial and mixed venous blood

$\mathrm{P}_{\mathrm{A}} \mathrm{CO}_{2} \quad$ alveolar partial pressure of $\mathrm{CO}_{2}$

To understand this equation we have to understand that pulmonary gas exchange is based on three principles: ventilation, diffusion and perfusion. ${ }^{10}$ The fundamental principle behind these three processes is the conservation of mass. Every molecule of $\mathrm{O}_{2}$ that enters the lungs has to go into the blood or be exhaled and every molecule of $\mathrm{CO}_{2}$ that leaves the lungs has to come from the blood or the atmosphere. ${ }^{10}$

$\mathrm{VO}_{2}=\mathrm{V}_{\mathrm{E}} \times\left(\mathrm{F}_{\mathrm{I}} \mathrm{O}_{2}-\mathrm{F}_{\mathrm{E}} \mathrm{O}_{2}\right)=\mathrm{V}_{\mathrm{A}} \times\left(\mathrm{F}_{\mathrm{I}} \mathrm{O}_{2}-\mathrm{F}_{\mathrm{A}} \mathrm{O}_{2}\right)$

And

$\mathrm{VO}_{2}=\mathrm{Q} \times\left(\mathrm{C}_{\mathrm{a}} \mathrm{O}_{2}-\mathrm{C}_{\mathrm{v}} \mathrm{O}_{2}\right)$

Combining these two equations

$\mathrm{V}_{\mathrm{A}} \times\left(\mathrm{F}_{1} \mathrm{O}_{2}-\mathrm{F}_{\mathrm{A}} \mathrm{O}_{2}\right)=\mathrm{Q} \times\left(\mathrm{C}_{\mathrm{a}} \mathrm{O}_{2}-\mathrm{C}_{\mathrm{v}} \mathrm{O}_{2}\right)$

Solve for V/Q and apply Dalton's law
$V_{A} / Q=8.63 \times\left(C_{a} O_{2}-C_{v} O_{2}\right) /\left(P_{1} O_{2}-P_{A} O_{2}\right)$

The constant allows for standardisation when the units used for $\mathrm{V}_{\mathrm{A}}$ and $\mathrm{Q}$ are $\mathrm{I} / \mathrm{min}, \mathrm{C}_{\mathrm{a}} \mathrm{O}_{2}$ and $\mathrm{C}_{\mathrm{v}} \mathrm{O}_{2}$ are $\mathrm{ml} / \mathrm{dl}$ and for $\mathrm{P}_{1} \mathrm{O}_{2}$ and $\mathrm{P}_{\mathrm{A}} \mathrm{O}_{2}$ are $\mathrm{mmHg}^{10}$

The same principle can be applied for $\mathrm{CO}_{2}$ except that the $\mathrm{CO}_{2}$ content of mixed venous and arterial blood are reversed because $\mathrm{CO}_{2}$ is being eliminated. ${ }^{10}$

$$
\mathrm{V}_{\mathrm{A}} / \mathrm{Q}=8.63 \times\left(\mathrm{C}_{\mathrm{V}} \mathrm{CO}_{2}-\mathrm{C}_{\mathrm{a}} \mathrm{CO}_{2}\right) /\left(\mathrm{P}_{\mathrm{A}} \mathrm{CO}_{2}-\mathrm{P}_{\mathrm{I}} \mathrm{CO}_{2}\right)
$$

These two equations explain why in an area of lung with reduced $V_{A} / Q$ ratio the $P_{A} O_{2}$ and $C_{a} O_{2}$ will fall greater than the $P_{A} C O_{2}$ will rise while in areas with high $V_{A} / Q$ ratio the $P_{A} O_{2}$ rises while $P_{A} C O_{2}$ falls. Therefore, low $V_{A} / Q$ areas affect $\mathrm{O}_{2}$ more and high $V_{A} / Q$ areas affect $\mathrm{CO}_{2}$ more. ${ }^{10}$

\section{The shunt equation:}

This equation gives a ratio of the shunt blood flow to total blood flow. Shunt blood flow is blood that is not exposed to any gas exchange. This may be areas of the lung with V/Q ratio of 0 or venous blood that enters the arterial system directly. ${ }^{11}$

Important in understanding and deriving this equation is to be able to draw a theoretical alveolus with blood being oxygenated and blood being shunted passed the alveolus.

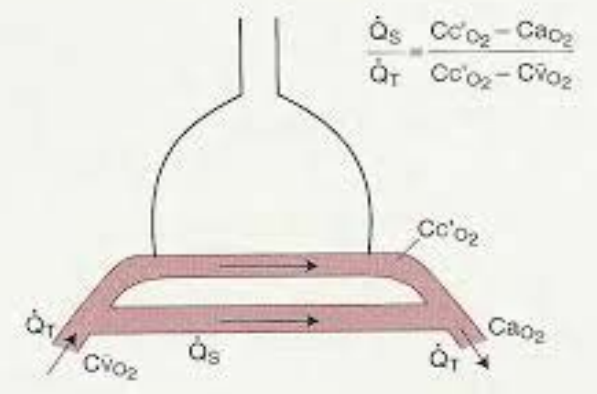

Figure 2: A visualisation of the shunt equation ${ }^{11}$

$\mathrm{Q}_{\mathrm{s}} \quad$ shunted blood flow

$\mathrm{Q}_{\mathrm{T}} \quad$ total blood flow

$\mathrm{CcO}_{2}$ end-capillary oxygen content

$\mathrm{CaO}_{2}$ arterial oxygen content

$\mathrm{CvO}_{2}$ mixed venous oxygen content

Flow entering the system $\mathrm{Q}_{\mathrm{T}} \cdot \mathrm{CvO}_{2}$ must equal flow leaving the system $\mathrm{Q}_{\mathrm{T}} \cdot \mathrm{CaO}_{2}$ but this flow is made up of two components shunted blood $\left(\mathrm{Q}_{\mathrm{s}} \cdot \mathrm{CvO}_{2}\right)$ and oxygenated capillary blood $\left[\left(\mathrm{Q}_{\mathrm{T}}-\right.\right.$ $\left.\left.\mathrm{Q}_{\mathrm{s}}\right) \cdot \mathrm{CcO}_{2}\right]$

Therefore

$$
\begin{gathered}
\mathrm{Q}_{\mathrm{T}} \cdot \mathrm{CaO}_{2}=\left(\mathrm{Q}_{\mathrm{s}} \cdot \mathrm{CvO}_{2}\right)+\left[\left(\mathrm{Q}_{\mathrm{T}}-\mathrm{Q}_{\mathrm{s}}\right) \cdot \mathrm{CcO}_{2}\right] \\
\text { Rearrange the brackets } \\
\mathrm{Q}_{\mathrm{T}} \cdot \mathrm{CaO}_{2}=\left(\mathrm{Q}_{\mathrm{s}} \cdot \mathrm{CvO}_{2}\right)+\left(\mathrm{Q}_{\mathrm{T}} \cdot \mathrm{CcO}_{2}\right)-\left(\mathrm{Q}_{\mathrm{S}} \cdot \mathrm{CcO}_{2}\right) \\
\text { Move } \mathrm{Q}_{\mathrm{s}} \text { to the left } \\
\left(\mathrm{Q}_{\mathrm{s}} \cdot \mathrm{CcO}_{2}\right)-\left(\mathrm{Q}_{\mathrm{s}} \cdot \mathrm{CvO}_{2}\right)=\left(\mathrm{Q}_{\mathrm{T}} \cdot \mathrm{CcO}_{2}\right)-\left(\mathrm{Q}_{\mathrm{T}}-\mathrm{CaO}_{2}\right)
\end{gathered}
$$


Simplify the brackets

$\mathrm{Q}_{\mathrm{S}}\left(\mathrm{CcO}_{2}-\mathrm{CvO}_{2}\right)=\mathrm{Q}_{\mathrm{T}}\left(\mathrm{CcO}_{2}-\mathrm{CaO}_{2}\right)$

Divide by $\mathrm{Q}_{5}$ and $\left(\mathrm{CCO}_{2}-\mathrm{CvO}_{2}\right)$

$\mathrm{Q}_{\mathrm{s}} / \mathrm{Q}_{\mathrm{T}}=\left(\mathrm{CcO}_{2}-\mathrm{CaO}_{2}\right) /\left(\mathrm{CcO}_{2}-\mathrm{CvO}_{2}\right)$

$\mathrm{CcO}_{2}$ is the end capillary oxygen content - blood that has been exposed to the alveolus and will always have the highest oxygen content.

Calculating $\mathrm{CvO}_{2}$ and $\mathrm{C}_{\mathrm{a}} \mathrm{O}_{2}$ is done by blood sampling from the central line and arterial line and is done using the following equations:

$$
\mathrm{CvO}_{2}=(1.34)(\mathrm{Hb})(\text { Sats })+\left(0.003 \cdot \mathrm{PvO}_{2}\right)
$$$$
\mathrm{CaO}_{2}=(1.34)(\mathrm{Hb})(\text { Sats })+\left(0.003 . \mathrm{PaO}_{2}\right)
$$

Measuring $\mathrm{P}_{\mathrm{c}} \mathrm{O}_{2}$ requires a catheter in the pulmonary vein and is technically difficult. As such it is assumed to be in equilibrium with the $\mathrm{P}_{\mathrm{A}} \mathrm{O}_{2}$ and therefore:

$\mathrm{CcO}_{2}=(1.34)(\mathrm{Hb})($ Sats $)+\left(0.003 . \mathrm{P}_{\mathrm{A}} \mathrm{O}_{2}\right)$

A reminder of the final equation:

$\mathrm{Q}_{\mathrm{s}} / \mathrm{Q}_{\mathrm{T}}=\left(\mathrm{CcO}_{2}-\mathrm{CaO}_{2}\right) /\left(\mathrm{CcO}_{2}-\mathrm{CvO}_{2}\right)$

Thus, by calculating $\mathrm{CcO}_{2}, \mathrm{CvO}_{2}$ and $\mathrm{CaO}_{2}$ from blood sampling it is possible to quantify the shunt fraction - which is the percentage of blood not exposed to ventilation. Normal shunt fraction is around 5\% and once it increases above 30\% increasing the $\mathrm{FiO}_{2}$ will not be able to increase $\mathrm{PaO}_{2} \cdot{ }^{12}$

\section{Conflict of interest}

The author declares no conflict of interest.

\section{Funding source}

None.

\section{ORCID}

T Leonard (iD https://orcid.org/0000-0003-4426-3972

\section{References}

1. West J. Respiratory physiology: the essentials. 9th ed. Philadelphia: Lippincott Williams \& Wilkins; 2011

2. Robertson HT. Dead space: the physiology of wasted ventilation. Eur Respir J. 2015;45:1704-16. https://doi.org/10.1183/09031936.00137614.

3. Augustyn A, Zeidan A, Zelazko A, et al. Dalton's law: Encyclopaedia Britannica, inc.; 2017 [cited 2020 September 22]. Available from: https://www.britannica. com/science/Daltons-law.

4. Tusman G, Sipmann FS, Bohm SH. Rationale of dead space measurement by volumetric capnography. Anest Analg. 2012;114:866-74. https://doi.org/10.1213/ ANE.0b013e318247f6cc

5. Cruickshank S, Hirschauer N. The alveolar gas equation. BJA Educ. 2004;4:24-7. https://doi.org/10.1093/bjaceaccp/mkh008.

6. Patel H, Kerndt CC, Bhardwaj A. Physiology, respiratory quotient. Treasure Island (FL): StatPearls Publishing. [updated 2020 April 29 cited 2020 September 22]. Available from: https://www.ncbi.nlm.nih.gov/books/NBK531494/

7. Petersson J, Glenny RW. Gas exchange and ventilation-perfusion relationships in the lung. Eur Respir J. 2014;44:1023-41. https://doi. org/10.1183/09031936.00037014

8. Dunn J-OC, Mythen MG, Grocott MP. Physiology of oxygen transport. BJA Educ 2016;16:341-8. https://doi.org/10.1093/bjaed/mkw012.

9. West J. Understanding pulmonary gas exchange: ventilation-perfusion relationships. J Appl Physiol. 2004;97:1603-4. https://doi.org/10.1152/ classicessays.00024.2004.

10. Wagner PD. The physiological basis of pulmonary gas exchange: implications for clinical interpretation of arterial blood gases. Eur Respir J. 2015;4:227-43. https:// doi.org/10.1183/09031936.00039214.

11. Dobby D, Chieveley-Williams S. Respiratory physiology - part 2. United Kingdom: World Federation of Societies of Anaesthesiologists; 2009 [cited 2020 September 22]; 160. Available from: https://www.frca.co.uk/Documents/160\%20 Respiratory\%20physiology\%20-\%20part\%202\%20compressed.pdf.

12. Butterworth J, Mackey D, Wasnick J. Morgan \& Mikhail's clinical anesthesiology. 5th ed. United States: McGraw-Hill Companies; 2013. 